\title{
MANAGEMENT: SOUTHEAST CONTINENTAL SHELF STUDIES
}

A Progress Report Submitted to

ENERGY RESEARCH AND DEVELOPMENT ADMINISTRATION

$$
\text { Contract } E(38-1)-901
$$

by

Skidaway Institute of Oceanography

P. 0. Box 13687

Savannah, Georgia 31406

David W. Menzel

Principal Investigator

August 1976 


\section{DISCLAIMER}

This report was prepared as an account of work sponsored by an agency of the United States Government. Neither the United States Government nor any agency Thereof, nor any of their employees, makes any warranty, express or implied, or assumes any legal liability or responsibility for the accuracy, completeness, or usefulness of any information, apparatus, product, or process disclosed, or represents that its use would not infringe privately owned rights. Reference herein to any specific commercial product, process, or service by trade name, trademark, manufacturer, or otherwise does not necessarily constitute or imply its endorsement, recommendation, or favoring by the United States Government or any agency thereof. The views and opinions of authors expressed herein do not necessarily state or reflect those of the United States Government or any agency thereof. 


\section{DISCLAIMER}

Portions of this document may be illegible in electronic image products. Images are produced from the best available original document. 
NOTICE

THIS DOCUMENT WAS PREPARED AS AN ACCOUNT OF WORK SPONSORED BY THE UNITED STATES GOVERNMENT. NEITHER THE UNITED STATES NOR THE UNITED STATES ENERGY RESEARCH AND DEVFIOPMENT ADMINISTRATION, NOR ANY OF THEIR EMPLOYEES, NOR ANY OF THEIR CONTRACIORS, SUBCONTRACTORS, OR HILIR EMPLOYEES, MAKES ANY WARRANTY, EXPRESS OR IMPLIED, OR ASSUMES ANY LEGAL LIABILITY OR RESPONSIBILITY FOR THE ACCURACY, COMPLEIENESS OR USEFULNESS OR ANY INFORMATION, APPARATUS, PRODIIST QR PROCESS DISCLOSLD, OR REPRESENTS THAT ITS USE WOULD NOT INFRINGE PRIVATELY OWNED RIGHTS. 
INTRODUCTION

Contract E(38-1)-901 provides for coordination of ERDA supported oceanographic research in the Southeast Atlantic area, Under the obligations of this contract, funded in December 1975, progress in the following areas is reported:

1) A synthesis of the major scientific conclusions resulting from work in the area.

2) Establishment of a Scientific Advisory Committee to assist in program direction and development.

3) Establishing liaison between participating scientists through the mechanisms of meetings and data exchange.

4) Coordination of the use of ships and other facilities.

\section{SUMMARY}

\section{Scientific Program}

ERDA's oceanographic program in the Southeast Atlantic currently is comprised of eight elements which may be viewed as follows: 1) a study of physical oceanographic factors forcing water motion on the continental shelf--the origin of Gulf Stream intrusions (Lee/RSMAS); 2) the physical oceanography of intrusions once isolated from the Gulf Stream (Pietrafesa/ NCSU); 3) nutrient fluxes induced by and chemical characterization of intrusions (Atkinson/SkI0); the effects of intrusions and coastal circulation on 4) micro-organisms (Pomeroy/Wiebe/UGA); 5) phytoplankton and zooplankton (Dunstan/Paffenhofer/SkI0);6) heavy metal distribution and inputs into coastal waters (Windom/SkI0, Cross/NMFS); 7) radioisotope geochemistry (Hayes/SRL, Cross/NMFS); 8) uptake and discharge of pollutants by marine organisms (Cross/NMFS). More site specific studies are those conducted in Key Biscayne (Thorhaug, Carpenter/RSMAS) and the Newport River-estuarine system (Cross/NMFS). 
Coordination procedures were initiated in December 1975. Our first efforts were directed toward assuring scientific and logistic compatibility between receritly finded contracts, deferring until later this year similar efforts involving those contracts funded prior to 1975. Newly funded contracts are those addressing continental shelf processes which this year have emphasized the study of Gulf Stream intrusions.

A. "Measurement of Gulf Stream and wind induced shelf circulation in the South Atlantic Bight." T. N. Lee.

This contract, funded in the summer of 1976, is in the start-up phase. Current meter arrays will be deployed along the edge of the shelf break and in Onslow Bay (Pietrafesa) in October 1976 and retrieved in February 1977. During each cruise a zig-zag track along the edge of the Gulf Stream with closely spaced cross sections of the shelf will be occupied to describe hydrographic conditions. A second current meter deployment at the shelf break and in the Georgia Bight is scheduled for June - September 1977 (Figure 1).

B. Onslow Bay Studies.

1) "Continental shelf processes affecting the oceanography of the South Atlantic Bight." L. P. Atkinson

2) "Continental shelf processes affecting the oceanography of the South Atlantic Bight." L.J. Pietrafesa

3) "The relationship of intrusions to phytoplankton, particulate carbon and herbivorous/omnivorous zooplankton of the South Atlantic Bight." W. Dunstan/G, A. Paffenhofer.

Initial studies of the hydrography and biology associated with Gulf Stream intrusions were conducted in the summer of 1975. An intensive survey is currently underway in Onslow Bay, North Carolina (July - August 1976). It is cxpected that the field work will be completed by September 1, 1976 with data work up and synthesis requiring another six-eight months. 


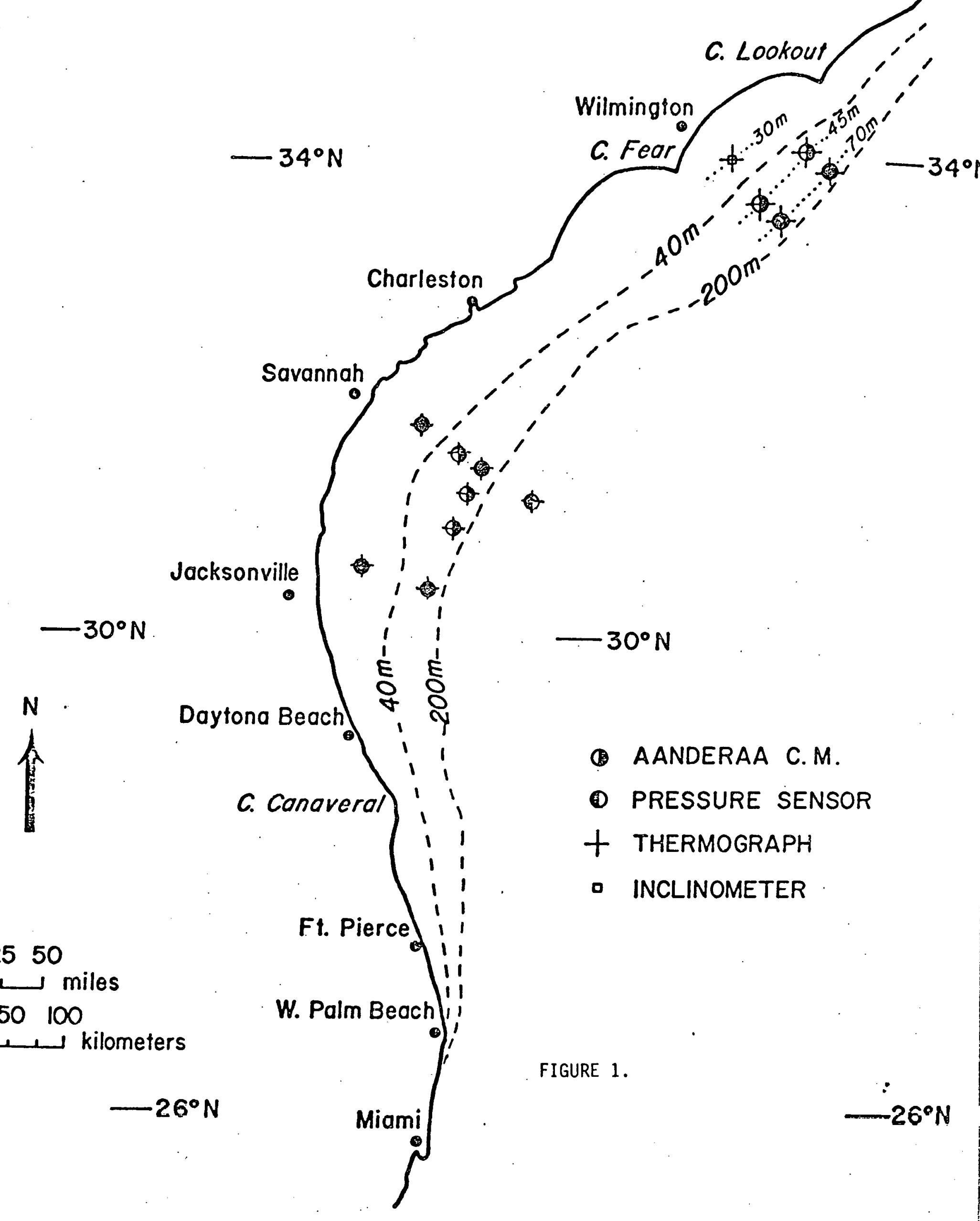


Work so far completed indicates that Gulf Stream intrusions represent a major and frequent (every seven to ten days) natural perturbation to the continental sheif ecosystem. It is a process that must essentially be evaluated against projected activities (perturbations) related to energy development on the continental shelf. The following summary conclusions substantiate this thesis:

1) The intrusion of Gulf Stream water on to the North Carolina shelf appears to be controlled by wind. Westerly winds induce a pseudoupwelling that has been described by current meter observations and intensive sampling grids for temperature, salinity and nutrients. If work this summer ('76) supports this conclusion it should be able to accurately predict the occurrence of intrusions from wind observations.

2) Preliminary volumetric analys is of Onslow Bay indicates that intruded water masses may occupy up to $50 \%$ of the volume of the Bay when they occur. These analyses combined with rate data (current meters) should provide the first true quantitative data on the mixing and flushing of continental shelf waters.

3) Analysis of satellite and existing oceanographic data indicates that the area off Charleston, South Carolina features a permanent wave in the Gulf Stream. The Stream travels almost due east, then north again causing a dome-like feature in isotherms and nutrient isolines.

4) Based on productivity measurements from four seasonal cruises in the Georgia Bight and estimates of potential $\mathrm{NO}_{3}-\mathrm{N}$ inputs from intrusions it appears that added nitrogen provides a major portion of that arinually required for primary production.

5) The levels of plant biomass associated with intruded waters is at least an order of magnitude higher than the surrounding waters. The plants are distinctly different in sizc and species type. 
6) Early observations indicate that secondary production (zooplankton) is also higher and of a different species composition than surrounding waters.

7) The results of comparative studies of heavy metal distribution in. intruded and "normal" continental shelf waters are not available at this time. Samples are being collected in August 1976.

Following the work in Onslow Bay, an area selected initially because of the persistence of intrusions and the lack of significant river input to complicate hydrographic/chemical interpretation, plans are to conduct a larger scale intensive investigation of the Gulf Stream-continental shelf interactions in the area from Savannah, Georgia south. At the same time physical and biological studies will be made of the nearshore zone. This area (out to $15 \mathrm{~km}$ ) is more productive in the Georgia Bight than in Onslow Bay. The object will be to determine the quality, quantity and cycle of primary and secondary production and to contrast this with that influenced by the intrusion process. In addition to the planned intensive surveys, monthly hydrographic/biological sections will be occupied in a line from Savannah, Georgia to the shelf break. The information obtained will be correlated with current meter data and used in itself to describe the seasonal cycles of plant and annual production.

C. "Trace element geochemistry of the South Atlantic Bight." H. L. Windom.

The major rivers emptying into the South Atlantic Bight have been sampled monthly since September 1975 to determine rate of input of copper. More recently $\mathrm{Ni}$ and $\mathrm{Zn}$ have also been measured, Water and air samples from the continental shelf, Gulf Stream and Sargasso Sea have also been collected and analyzed for $\mathrm{Cu}$. Tentative conclusions are: 
1) Rivers account for the major input of $\mathrm{Cu}$ to the South Atlantic Bight.

2) The average concentration in continental shelf water is $0.1-0.2 \mu \mathrm{g} / 1$, most probably occurring as complexes.

3) Complexation capacity appears to be related directly to total amino acid nitrogen.

4) The residence time of $\mathrm{Cu}$ on the continental shelf is approximately three months.

D. "Flux of energy and essential elements through the continental shelf ecosystem." Pomeroy/Wiebe.

The immediate goal of this work is to develop indices of condition of continental shelf waters that may help in determining the impact of energy development on the continental shelf. Emphasis is placed on the microorganisms and phytoplankton on the assumption that these organisms are the most sensitive to perturbation. In the first year (1975-76) cruises were occupied in the area between North Carolina and Georgia. Considerable effort was directed at automating analytical procedures so that rapid synoptic overviews can be obtained. Because of the number of personnel involved and the size of ships available, the field work has been largely conducted independently of other investigators.

E. As noted earlier we have made little effort to date to strengthen liaison between the above "new" and established contracts. The latter include studies being conducted by Carpenter and Thorhaug at RSMAS, Cross at NMFS, and Crawford at SRL. This subject will be discussed further below.

\section{Scientific Advisory Committee}

The Southeast Atlantic Scientific Advisory Committee is composed of Timothy Parsons (biology) of the University of British Columbia, Karl Turekian 
(chemistry) of Yale University, and Robert Smith (physical oceanography) of Oregon State University. The appointment of a geologist, stipulated as a fourth member in the contract proposal, has been deferred since no research contracts now funded deal in that area.

The Committee, established in March '76, has not been active to date. A meeting is scheduled in early October 1976 after which a report will be issued in which the "general health" of the program and recommended expansion will be addressed.

\section{Meeting - Liaison}

Considering that three meetings involving various investigators funded by ERDA were held in 1976 a general annual meeting of all concerned was deferred until October.

1) On June 3 a meeting was held in Atlanta, Georgia involving all contractors involved in the physical oceanographic program. Attendees included W. Forster (for ERDA), L. Pietrafesa, L. Atkinson, D. Hayes, J. Suich, T. Lee and D. Menzel. The purpose was to determine how the combined resources of the physical oceanographic group could be most effectively used. Discussions were designed also to clarify where effort should be centered in modelling efforts and to assure feedback between the modelling and field programs. At the same time a mutually acceptable schedule for current meter deployment, hydrographic observations and other logistics was achieved. This schedule is discussed under I ( $A$ and $B$ ) above.

2) A press briefing organized principalily by W, McCann and P. Garon of ERDA Public Relations Office was held on May 3, 1976 at the Skidaway Institute. This provided a means not only to publicize ERDA's oceanographic program but allowed the Principal Investigators to describe and discuss their work with each other. Attending the meeting as spokesmen for ERDA were 
W. Forster, W. McCann and P. Garon, F. Cross, D. Hayes, L. Pomeroy, L. Atkinson, L. Pietrafesa, W. Dunstan, G.-A. Paffenhofer and D. Menzel. Members of the press attending were Frances Parker, Howard Payne and Allen Royce of the National Geographic; Mr. Dosa, Voice of America; Mr. Seabrook, Atlanta Journal; H. Willard, Washington Post; Franklin Young, Florida Times Union; Gardner Miller, Charleston News and Courier and David Salisbury, Christian Science Monitor.

3) At the annual meeting of the American Society of Limnology and Oceanography a symposium was held on the oceanography of the Georgia Bight at which early results and tentative conclusions of research so far completed were presented. ERDA supported investigators who presented papers were as follows:

D. Menzel - "Introduction and Overview"

T. Lee - "Physical Processes in the South Atlantic Bight"

L. Pietrafesa - "Current Meter Observations in Ons low Bay"

L. Atkinson - "Hydrographic Observations in Onslow Bay"

G. A. Paffenhofer - "Particle Concentrations in Intruding Water Masses"

W. Dunstan - "Characterization of Phytoplankton Populations Resulting from an Intruding Water Mass"

E. Hofmann - "Ecological Modelling using Separation Transformation Theory".

4) A meeting for all ERDA supported investigators and the Scientific Advisory Committee is scheduled for October 11-12, 1976 in Atlanta, Each investigator will be asked to describe research currently underway. Additional agenda items include examining means to coordinate research efforts, in particular to identify mutual interests, possible scientific interaction and to coordinate the field sampling programs. This will be the first 
formal involvement of the Scientific Advisory Committee. Their assistance will be solicited to point out strengths and weaknesses in the program and to recommend where future efforts should be encouraged.

IV. Ship Use and Logistics

A major and consuming expense of oceanographic research is the cost of ship operations. To minimize this expense we have routinely circulated ship schedules to all potential ERDA users. Currently use is centered primarily on the ADVANCE II (Pietrafesa), the R/V EASTWARD (Pomeroy), R/V COLUMBUS ISELIN (T. Lee) and R/V BLUE FIN (Atkinson, Dunstan, Paffenhofer, Lee). The ADVANCE II while satisfactory for current meter deployment is generally considered substandard as a research platform by those investigators who have tried to use her. The EASTWARD and ISELIN are fully capable research vessels but have long scheduling lead times and are prohibitively expensive for more than occasional use. The BLUE FIN, a small coastal vessel, has been effectively employed in Onslow Bay and for continental shelf studies off Georgia. The main feature limiting more extensive use of the BLUE FIN are probable limitations during the winter months due to sea keeping ability and the lack of adequate laboratory space for multidisciplinary cruises.

In May 1976 the PALUMBO was transferred from the Puerto Rico Nuclear Center to the Skidaway Institute. Assuming that sufficient funds are made available to correct a number of deficiencies, this vessel should be able to accommodate most currently funded ERDA related research. After transfer to the Skidaway Institute the vessel has been surveyed and the bottom and sides painted. The surveyor's report should be available within the next two-three weeks after which firm estimates for overhaul can be made. Before funds are committed for this purpose however, it is essential that the ship's stability features be determined. The builder cannot provide line drawings of the hull, the results of inclination tests, or load line 
calculations each of which is required to provide stability data, This information is required to legally operate the ship under maritime law.

The time required to obtain stability information, cost estimates for improvements and to carry out the necessary work is approximately four months. Some work has been initiated using funds from this contract after approval of the Savannah River Operations Office, Completion of the work is dependent upon when sufficient funds for the purpose are made available. 